Krystyna Pieniążek-Marković

Instytut Filologii Słowiańskiej

UAM Poznań

http://dx.doi.org/10.18778/8088-249-2.03

\title{
CHORWACKIE SPOTKANIA Z KULTURĄ ISLAMU W DZIEWIĘTNASTOWIECZNYM PODRÓŻOPISARSTWIE WE WŁADZY STEREOTYPÓW
}

Wiek XIX w literaturze chorwackiej, podobnie jak w innych literaturach europejskich, jest czasem rozkwitu relacji z podróży. Publikowane sprawozdania $\mathrm{z}$ wypraw wskazują, że chętnie wybierane kierunki chorwackich peregrynacji wiodły na Wschód i Południe. Dawały one możliwość konfrontacji z kulturą islamu, gdyż oznaczały pobyt w imperium osmańskim: Turcji (rzadziej) oraz sąsiedniej Bośni (częściej), czyli „gnieździe szerszeni”, jak przed wyprawą do Bihacia, „stolicy chorwackiej Turcji”, pisał w 1860 r. duchowny Adolfo Veber Tkalčević [1998: 93-94]. Tkalčević przygotował także obszerną relację z ekspedycji do wschodniego Rzymu [1886]. Najbardziej znani chorwaccy dziewiętnastowieczni peregrynaci, opisujący przebieg swych podróży do Bośni to Matija Mažuranić (jego utwór Pogled u Bosnu [1842] uważany jest za pierwszą romantyczną realizację gatunku, choć wcześniej podróże ukazywały się w prasie), Ivan Kukuljević Sakcinski [1857], Kliment Božić (Slike iz Bosne, „Vienac” 1869), ksiądz Mihovil Pavlinović [1874], a także urodzeni i posługujący w Bośni i Hercegowinie franciszkanie: Ivan Frano Jukić oraz Grgo Martić ${ }^{1}$.

Chorwackie zainteresowanie orientalną i osmańską Bośnią miało swe źródło w duchu romantyzmu, ideologii iliryjskiej (a następnie jugoslawistycznej spod znaku Josipa Juraja Strossmayera) oraz pobudkach osobistych. Relacje z podróży chorwackich autorów po ziemiach Imperium Osmańskiego stanowią, więc część europejskiego dorobku romantycznych peregrynacji po terenach egzotycznych, lecz nie odzwierciedlają fascynacji Orientem i raczej ilustrują romantyczne zabarwienie życia niż literatury. Iliryjsko-jugoslawistyczne idee

1 Obaj bracia zakonni zaliczani są do chorwackiego piśmiennictwa podróżniczego ze względu na związki z chorwackimi kręgami kulturalnymi i politycznymi oraz na publikację wspomnień w tamtejszych periodykach, jednak wpisanie ich dorobku do korpusu literatury chorwackiej nie oznacza identyfikacji etnicznej [zob. Falski 2007: 52]. 
kazały natomiast chorwackim podróżnikom oraz bośniackim franciszkanom badać nastroje wspólnotowe w Bośni ${ }^{2}$. Jej wyzwolenie spod panowania tureckiego było jednym z ważniejszych marzeń przywódcy ruchu iliryjskiego Ljudevita Gaja. Impulsy osobiste pchały zaś do odbycia podróży ku korzeniom, do swoistego „zwrotu pamięciowego" rodzin pielęgnujących wspomnienia o bośniackich stronach rodzinnych i kraju przodków. Taki charakter miała podróż Ivana Kukuljevicia Sakcinskiego, zresztą spokrewnionego z franciszkaninem Grgo Marticiem. Veber Tkalčević wskazuje także czwartą motywację, silnie emocjonalnie nacechowaną a wynikającą z podboju części ziem chorwackich przez Turków i nadziei na upadek imperium: „Turska je i zato znamenitija za nas od ikoje druge države, što je turstvo vrutak goleme nesreće naše; ono nas je bo razstavilo, razdružilo i uzastopce progutalo; a ono mora biti u padu vrelo sreće naše” [Veber Tkalčević 1998: 94].

Ze względu na uwarunkowania historyczno-społeczno-kulturowe, wynikające z usytuowania Chorwacji na zachodnich rubieżach Europy, w chorwackim imaginarium bardzo wcześnie wykształcił się ideologem przedmurza chrześcijaństwa, wizja Chorwacji chroniącej kontynent przed nadciągającym ze Wschodu dzikim i niebezpiecznym obcym (Tatarem, Turkiem, a w wieku XX prawosławnym Serbem) - z którym toczono boje, tracąc w najtragiczniejszym okresie dwie trzecie terytorium - oraz towarzyszący im orientalistyczny (w rozumieniu Edwarda Saida), a zwłaszcza antyturecki dyskurs. Wizerunek wschodniego barbarzyńcy, zdobywcy i ciemiężyciela już od średniowiecza wzmacniała literatura [zob. Dukić 2004], a przypięczętowały arcydzieła baroku i romantyzmu: Osman Ivana Gundulicia i Smrt Smail-age Čengicia Ivana Mažuranicia.

2 Charakter misji szpiegowsko-zwiadowczej, realizowanej w ramach iliryjskiej ideologii, miała wyprawa Matiji Mažuranicia, który podróżował po Bośni nielegalnie, choć za cichym przyzwoleniem Wiednia. Władzom monarchii zależało na utrzymaniu dobrych stosunków z Portą, dlatego poza ich interesem pozostawało wydawanie oficjalnej zgody na podróż do Imperium Osmańskiego osób, które namawiałyby do powstania. Do relacji „służbowych” zaliczyć można także teksty franciszkańskie, powstałe w efekcie pasterskich podróży, mających dostarczyć wiedzy na temat sytuacji wiernych. Spojrzenie bośniackich duchownych uruchamia perspektywę wewnętrzną oglądu Bośni i Hercegowiny, natomiast opis Mažuranicia kreowany jest z perspektywy zewnętrznej. Pozostałe wyprawy (Sakcinskiego, Pavlinovicia i Tkalčevicia), wpisujące się w zewnętrze spojrzenie $u$ Bosnu, uznać można za krajoznawcze, jednak uwaga zwiedzających, skoncentrowana na topografii, stanie dróg czy fortyfikacji, każe sądzić, że wszyscy peregrynaci, reprezentujący przecież elity świeckie i duchowne, oceniali zwiedzane ziemie w kontekście marzeń o rychłym upadku osmańskiej potęgi i przyłączenia tych terytoriów (odwiecznie uznawanych za własne) do programów narodowych. 


\section{Zderzenie cywilizacji i przesądów}

Pierwsza dziewiętnastowieczna chorwacka relacja z wyprawy do Bośni i Osmańskiego Imperium, Pogled u Bosnu, jest doskonałym przykładem pozostawania pod władzą stereotypowych wyobrażeń oraz utrwalania negatywnych heterostereotypów ${ }^{3}$. Krótki opis pierwszego spotkania bohatera Matiji Mažuranicia, Szwaba ${ }^{4}$, z reprezentantem świata islamskiego, stanowi klasyczne zderzenie z niebezpiecznym obcym. Bosy, brudny i w podartych szarawarach, mimo zimy, spahis ${ }^{5}$ wywołuje strach i konsternację; zaskoczenie nędznym i niedbałym strojem, które będzie także udziałem Kukuljevicia Sakcinskiego ${ }^{6}$, pokazuje utrwalenie wyobrażenia o zamiłowaniu muzułmańskiej arystokracji do przepychu [zob. Seroka 2013: 93 ] ${ }^{7}$. Brud i zaniedbanie dostrzeżone u spahisa, pozostawiają trwałe piętno na percepcji podróżnika, staną się w tekście Mažuranicia, oraz jego następców, synonimami islamskiego terytorium, jego mieszkańców i otaczającego ich świata kultury materialnej.

Niehigieniczne warunki, zwyczaje i styl życia (np. wspólne palenie cybucha czy jedzenie rękoma) - odbierane tak przez przybysza uznającego normy własne/europejskie za jedyne właściwe - w najbardziej dokuczliwy sposób dawały o sobie znać podczas noclegów w przydrożnych chanach ${ }^{8}$. „Dawni podróżni nie darzyli sympatią gospód na poboczach dróg, gdyż były one rządzone «całkowicie na modłę turecką». Oznaczało to, że wspólne pokoje z gołymi ścianami, a jeszcze częściej pozbawione okien, i sprzętów, z wyjątkiem słomianego posłania, używane były do jedzenia, palenia i spania" [Jezernik 2007: 24]. Opisując warunki $\mathrm{w}$ zajazdach czy tureckie drewniane chaty wykonane $\mathrm{z}$ gałęzi i zwierzęcych odchodów, chorwacki obserwator nie szuka przyczyn zastanej sytuacji. Tego rodzaju refleksje pojawiają się natomiast u franciszkanów, którzy retorycznie pytają: „bieda to czy niechlujstwo?” [zob. Pieniążek-Marković 2014b].

3 Więcej na ten temat: Pieniążek-Marković 2013 oraz 2014a.

4 Bohater reprezentuje Szwaba, tak bowiem, niezależnie od narodowości, zwani byli mieszkańcy austro-węgierskiej monarchii przez mieszkańców Imperium Osmańskiego, ci zaś - w zależności od wyznania - nazywani byli Turkami lub Bośniakami, przy czym Turek oznacza słowiańskich poturczeńców, natomiast etnicznych Turków nazywano Osmanlije.

5 Turecki odpowiednik europejskiego rycerza.

${ }^{6}$, „...] priprosto odeven $[\ldots]$ nije baš mnogo priličio begu, što će po turski reći grofu” [Kukuljević Sakcinkski 1997: 332]. Dla podróżującego w 1884 r. Vebera Tkalčevicia łata jest już znakiem rozpoznawczym Orientu [Veber Tkalčević 1886: 7].

7 „Njihove su haljine jako skupe; jedno zato, što su strašno široke, a drugo, što su izvezene zlatom i kojekakvimi gajtani. Liepe halje, liepo oružje i liep čibuk, to jim je sva dika" [Veber Tkalčević 1998: 101].

$8,[. .$.$] hani su najviše loši, tako da tko u njem samo jednu noć prespava, već nikada$ neće zaboraviti te riječi h a n” [Veber Tkalčević 1998: 97]. 
Rozpoznawalnym znakiem islamskiej Bośni były także wszechobecne błota, bezdroża, opłakany stan dróg i zajazdów oraz ujadające stada psów [zob. Pieniążek-Marković 2014a]. Brak dróg i mostów lub ich tragiczna, jakość sytuowały Bośnię poza granicami Europy, czyli poza „cywilizacją koła”. Sakcinski zwraca również uwagę na inne przejawy kultury materialnej, zwłaszcza architektury (plecione z gałęzi kramy, przypominające szałasy, drewniane domy z papierem w oknach zamiast szyb), na ruiny twierdz, o które nikt nie dba, zapuszczone pola uprawne, na lenistwo mieszkańców nie troszczących się o dobro własne i wspólne. Opisuje podwórza i wnętrza mieszkań ${ }^{10}$, chanów, čaršiji, meczetów. Odnotowuje zaskakujące go rozwiązania architektoniczne, których jednak nie łączy z obowiązującym prawem i zwyczajem, jak kraty w oknach izb kobiecych czy szczelne ogrodzenia podwórek chroniące domowników (zwłaszcza kobiety) przed okiem ciekawskiego przechodnia. Ogólny obraz Bośni wyłaniający się z kart chorwackich podróżników to zacofana, obca, mroczna, tajemnicza i niebezpieczna kraina, po której z trudem można się poruszać, zaiste „dzika Europa” bez dróg i mostów, skazująca wędrowca na tułaczkę po bezdrożach, nieustanne przebywanie w sytuacji granicznej, w stanie zagrożenia życia ze strony „dzikich ludzi” i niesprzyjającego klimatu. W przeciwieństwie do opisów Grgi Marticia, Frano Jukicia i Ivana Kukuljevicia Sakcinskiego, prezentujących Bośnię, jako biedny kraj z nieopisanie piękną przyrodą i bogatymi zasobami naturalnymi, z których jednak mieszkańcy nie potrafią czerpać, dla narratora Matiji Mažuranicia bośniacka górzysta przyroda i zimowa aura uzupełniają przerażającą wizję kraju zagrażającego życiu (podróżując w grudniu i styczniu, przemarzł i poważnie zachorował).

\section{Relacje międzyludzkie. Nieludzkie oblicze Turków}

Bośnia w relacjach z podróży jawi się jako teren szczególnie niebezpieczny dla chrześcijan, nękanie ich, nader często prowadzące do śmierci, Mažuranić opisuje jako rodzaj muzułmańskiej rozrywki lub jako środek wiodący do realizacji konkretnego celu (np. zdobycia pięknej chrześcijanki):

9 Z tego względu zachodni podróżnicy w drodze na Wschód chętniej wybierali drogę morską. Turcy tradycyjnie poruszali się na koniach, wielbłądach, osłach lub mułach, dlatego na terenie Imperium Osmańskiego rzadko spotykano powozy. Veber Tkalčević dostrzega w tej zależności rodzaj kwadratury koła: „Turci neimaju drumovah, što se nikad ne voze, a ne voze se, što neimaju drumovah, eto ti savršena obrata sudovah. Siromasi idu pješke, bogatci jašu, a oboje se može preko jamah" [1998: 94].

${ }_{10}$ Drobiazgowe opisy sposobów ochrony domu przed światem zewnętrznym ( $k a-$ pija, kaplidžik, mandala), podziału pomieszczeń wnętrz (kuća, harem, mutfak, ahar) oraz ich wyposażenia zawiera także tekst Vebera Tkalčevicia [1998: 96-97]. 
Kad jih se nakupi mlogo, onda poviče jedan: «Valaha, dobar čověče, što ćemo sad?» - Onda se počmu hvaliti: koi znade kakova hrdjava i strašljiva vlaha da ima lěpu ženu. Tada se sve na družtva razděle, pak idje svako družtvo svomu Vlahu. Nego u slobodna Vlaha ne smiju nipošto dirati dok je živ. Ako ima jako lěpu ženu, tako Turci najprvo gledaju da njega ubiju, a potlě š njegovom udovicom rade što oni znaju. Najnesrěćnije su one děvojke kojim je narav lěpotu podělila; jerbo nikakav kršćanski momak ne smě u nju ni gledati, a kamoli da bi ju uzeo za ženu. S toga uzroka su sve najlěpše prisiljene poturčit se [Mažuranić 1842: 21].

Przekonanie o absolutnej nietolerancji wobec nie-swoich było tak powszechne wśród chorwackich podróżników, że wybierając się w drogę do Bośni duchowny Mihovil Pavlinović postanowił się zamaskować i przywdział turecki strój ${ }^{11}$. Ciekawość i misja, które gnały Chorwatów na teren europejskiej (i chorwackiej) Turcji łączyły się ze strachem wpisanym w zbiorową pamięć i utrwalonym przez literaturę oraz „potwierdzonym” przez relację Matiji Mažuranicia, który informował o całkowitym nieposzanowaniu mienia i życia ludzkiego, o powszechności i bezkarności kradzieży, gwałtu, zbrodni. Przedstawił muzułmanów jako barbarzyńców, groźnych także dla siebie nawzajem: „čas jedan s drugim živu kao bratja, a čas opet gledaju, kako bi jedan drugomu ulomili vrat" [Mažuranić 1842: 26]. Szczególną wzajemną niechęć (wręcz nienawiść) obserwuje między muzułmańskimi Boszniakami i Turkami osmańskimi.

Badacze relacji Mažuranicia zwracają jednak uwagę na uproszenia i przekłamania autora, który dokonuje uogólnień na podstawie incydentów, kontaktu $\mathrm{z}$ dworem Mustafa-paszy Babicia i krótkiego pobytu, trwającego niecałe dwa miesiące, przy tym częściowo w chorobie i gorączce [zob. Tkalac 1945: 83; Franić 1983: 48; Paić-Vukić, Čaušević 2007]. Negatywnego obrazu nie niwelują, choć nieco łagodzą, dwie sceny ukazujące pozytywny wizerunek muzułmanina. W pierwszej Berberbaša oddaje własną szablę narratorowi, by mógł się bronić przed atakami Omer-čauša. Druga dotyczy przejawów miłosierdzia, którego ciężko chory bohater doświadczył od wyznawców islamu w drodze powrotnej. Troskę o walczącego ze śmiercią chrześcijańskiego podróżnika „iz Njemačke” wykazało kilka osób: spahis (właściciel chanu), jeden z gości (pokrywając koszty wyżywienia chorego), modlący się za umierającego hodża oraz odprawiający nabożeństwo muzułmanie, którzy pozwolili cierpiącemu innowiercy pozostać w tym samym pomieszczeniu. Wyeksponowanie „ludzkiej twarzy” słowiańskich muzułmanów (wiadomo, że etnicznych Turków mógł autor spotykać

11 „[... ] sad sam ja bradat i brkat, pod fesom i pod turskim pusatom, s glavom u torbi. Kad mi starogradski mladi župnik Andrija Friš, danas kanonik u Rimu, opazio tursko odijelo: i čakšire, i pasove, i jačerme, i svilaje i revolvere, ublijedio: da neće sa mnom prijeko ako sve to ne sakrijem. «Kako to, po Bogu brate? U nas se kaže da po Bosni, ako ćeš mirno da prođeš, valja putovati po tursku»” [Pavlinović 2002: 177]. 
sporadycznie ${ }^{12}$ ) nie leżało jednak w interesie opowiadacza i byłoby sprzeczne $\mathrm{z}$ jego polityczną misją.

Ukazanie barbarzyństwa przedstawicieli islamu miało na celu wzbudzenie europejskiego współczucia dla zamieszkujących osmańskie imperium chrześcijan i podjęcie wspólnej walki z Turcją. W ocenzurowanym i nieopublikowanym fragmencie Pogleda u Bosnu, autor podsumowuje: „Sada moja gospodo svitle i izobražene Europe, iz ovoga možete uviditi zloću i opačinu s kojom se turci služe protiva kerstjanom" ${ }^{13}$. W Anglii dopiero pod koniec lat osiemdziesiątych XIX w. (czyli po ponad czterdziestu latach od podróży Mažuranicia, głównie za sprawą publicznych wykładów Georginy Mackenzie i Adeliny Irby, podróżujących po Bułgarii, Serbii, Macedonii i Bośni, które Anglikom przekonanym, że Bałkany zamieszkują Turcy lub Grecy „odkryły” istnienie Słowian południowych) pojawiły się głosy świadczące o świadomości, w jakiej sytuacji znajdują się podbite przez Turków narody [Todorowa 2008: 213-215].

\section{Relacje międzyludzkie. Muzułmanie z ludzką twarzą}

Matija Mažuranić przebywał na terenie Bośni na przełomie roku 1839 i 1840, natomiast w 1857 r. swą podróż do bośniackiego kraju pradziadów, który, jak informuje we wstępie, „poradi različne vlade i upravljanja” [1997: 327] jest teraz bardziej obcy i odległy od Rzymu i Paryża - odbył Ivan Kukuljević Sakcinski. W dzienniku Sakcinskiego reprezentanci islamu wyłamują się ze stereotypu dzikusów, owszem bywają milczący (tureckim zwyczajem ma być np. nieodpowiadanie na pytania ${ }^{14}$ ), ubrani nieodpowiednio do pozycji społecznej, jednak głównie są radośni, przyjaźni i gościnni. Nieliczne sarkastyczne uwagi pod adresem Turków zdarzają się na początku wyprawy (i wstępnych partiach tekstu), jednak ocena bośniackiego towarzystwa zmienia się bardzo szybko, już podczas pierwszego odpoczynku w przydrożnym zajeździe. Perspektywa Sakcinskiego różni się w głównej mierze, dlatego, że nie podróżował on incognito, jako szukający pracy rzemieślnik (jak ukrywający prawdziwe intencje Matija

12 Etniczych Turków było w Bośni niewielu, a muzułmanie, z którymi się kontaktował byli Boszniakami: „on uopće ne opisuje običaje, mentalitet i navike Turaka: i Mustafa-paša Babić, i Omer-čauš, i berber-baša i putnici koji ga njeguju u hanu, sve su to Slaveni, Bošnjaci” [Paić-Vukić, Čaušević 2007: 189].

13 M. Živančević, Nepoznati putopis Matije Mažuranića?, Zbornik Matice srpske za književnost i jezik, knj. 22, sv. 1, Novi Sad, 1974, s. 38. Cyt za: [Paić-Vukić, Čaušević 2007: 190].

14 W stereotypizacji i stygmatyzacji idzie dalej Veber Tkalčević, twierdząc, że tureckie milczenie wynika z niewiedzy: „o čem da govori čovjek, koji nije ništa učio, ništa čuo, nigdje bio" [1998: 103]. 
Mažuranić), lecz jako szanowany przedstawiciel arystokracji, dla którego wiele drzwi stało otworem; miał też zawsze przewodnika, umówiony nocleg i dobrego konia, (o co najczęściej dbali gospodarze). Można odnieść wrażenie, że Sakcinski koncentrował się na tym, co wspólne i bliskie, na szukaniu podobieństw, a nie różnic, podkreślał, że w pogodnych młodych muzułmanach rozpoznaje słowiańską naturę. Poznani wyznawcy islamu w oczach Sakcinskiego nie tylko są gościnni, uprzejmi, przyjaźni, sprawiedliwi i lubiani przez poddanych, ale także światli i świadomi regresu, jakiego od stuleci doświadcza Bośnia, nawet w porównaniu z innymi krajami słowiańskimi, nie mówiąc już o „wyobrażonej” Europie $^{15}$. Reprezentujący wyższe szczeble islamskiej drabiny społecznej begowie, agowie czy knezowie okazują się doskonałymi partnerami do dysputy na temat sytuacji gospodarczej w Bośni, reform i postępu, a ,jeden serdeczniejszy od drugiego" [Kukuljević Sakcinski 1997: 366].

Dzięki różnorodnym kontaktom Sakcinski zdobywa wyobrażenie o Bośni odbiegające od czarno-białych klisz odrodzeniowych, a zawarta w tekście krytyka, dotycząca głównie zapuszczonych pól uprawnych i niewykorzystanych dóbr naturalnych, skierowana jest nie, jak u Mažuranicia, pod adresem Turków (isla$\mathrm{mu}$ ), lecz całego narodu bośniackiego, niezależnie od konfesji (zwłaszcza leniwego ludu, najbardziej zaś boleje nad tym, że katolicy nie dbają o swój język, naród i zwyczaje, s. 374) [zob. Dragičević 2010: 259]. Sakcinki chwali jednostki i gani kolektyw, odwołując się wówczas do stereotypowych terminów, znanych z orientalistycznego dyskursu: barbarzyńcy, dziki kraj „błotem płynący”. Dostrzega jednak wyraźne linie demarkacyjne pomiędzy bośniackimi (słowiańskimi) wyznawcami islamu oraz przedstawicielami Turków Osmańskich, którzy - w jego ocenie - dla wszystkich Bośniaków są ucieleśnieniem obcych. Wbrew, bowiem nazwie Turcy, stosowanej wobec bośniackich wyznawców islamu i wskazującej na jed-

15 „Ovo biaše družtvo $s$ kojim sam morao čitav sat provesti, pa mi biaše ipak milije negoli mnoga druga, takozvana ugledna naša družtva. Bosanski Turčin i kèršćan bistar je i zreo u svome razgovoru i u mislih; njegov jezik liep je i uglađen; njegovo je ponašanje surovo ali otvoreno i sèrdačno" [Kukuljević Sakcinski 1997: 333]. Sakcinski dostosowuje się do panujących zwyczajów i choć z ulgą zatrzymuje się w miejscach oferujących „europejskie" warunki, czyli zwłaszcza osobne pokoje, a nie - jak w chanach - tylko osobne lóżka, to nie piętnuje muzułmańskich zwyczajów, zwłaszcza, gdy poznaje je w domach bośniackiej elity, gdzie okazywane są mu wyrazy szacunku: „Na stolu nije bilo ni vilicach ni noževah, stoga sam počeo i ja vaditi, osim čorbe, sve liepo rukom iz zdielah, što ih sluge izmienice u sredinu stola stavljaše. Bilo je jestbinah svakojakih, jušadi, zelenine, pečenoga, testarine i napokon pilav, bez kojega ima riedko turskoga ručka. $U$ čašama bila je miesto studene vode ili vina, niekakva sladka voda, po svoj prilici sa šećerom pomiešana. Poslie ručka oprasmo si opet ruke i bismo podvoreni čibukom, kafom i šerbetom. U znak osobitoga štovanja, metnuše nam na goruću lulu još niekakvo mirisno dèrvo, što smo dobro begenisali tj. dobro nam je činilo" [Kukuljević Sakcinski 1997: 337]. 
ność konfesji oraz przynależności etnicznej, bośniaccy muzułmanie - jak wynika z jego obserwacji - nie zrezygnowali ze swych słowiańskich tradycji czy języka ${ }^{16}$.

Niezależnie od dobrego przyjęcia, narrator ma świadomość, że jest w Bośni obcy, ale też niejednokrotnie przemawia językiem kolonizatora, który ratunek dla kraju tkwiącego w średniowiecznej stagnacji, widzi w oświeceniowej pracy u podstaw, modernizacji oraz budzeniu świadomości etnicznej: „Duh prosvjete i napredka može se usaditi u Bosni samo putem probuđene narodnosti i samosvijesti, dok ova spava, ostat će i Bosna u barbarskom mèrtvilu s kojim se ne može nijedan narod spasiti” [Kukuljević Sakcinski 1997: 374]. Obserwacje Sakcinskiego, prowadzone z perspektywy Europejczyka, prowadzą do radykalnego osądu ludności: przemiana kraju wymaga „wymiany” mieszkańców, inni (w domyśle: pracowici i oświeceni Europejczycy) zamieniliby w raj tę teraz „cuchnącą, choć urodzajną ziemię” [Kukuljević Sakcinski 1997: 340]. Największym przekleństwem dla kraju było, jego zdaniem, nie osmańskie zniewolenie, lecz lenistwo ludu, dlatego Sakcinski w odróżnieniu od licznych europejskich turystów zwiedzających Bałkany nie widzi potrzeby zmiany władzy. Na wieść o poszukiwaczach skarbów (głównie starożytnych pamiątek) Kukuljević konstatuje: „Da oni više rade i da se više uče, ne bi tražili tuđe namišljeno bogatstvo, već bi ga svojim trudom stekli, kao što čine izobraženi narodi” [1997: 358]. Słowa krytyki wkłada także w usta begów obeznanych z kulturą i prądami umysłowymi Europy. Żal nad zapóźnieniem Bośni, nad stanem dróg i ograniczonością ludu wyraża np. Derwisz-beg z Trawnika. Przy okazji słowami bega Sakcinski wypowiada przekonanie o kształcącej roli podróżowania: „tuži se na drumove i na glupost ljudih, koji niesu nikuda putovali i ništa vidjeli” [1997: 366-367].

\section{Za mało lub za bardzo europejscy}

Pomimo że w relacji Sakcinskiego nie zostało odnotowane ani jedno spotkanie z „barbarzyńskim” Turkiem, w podsumowaniu autor zamieszcza obiegowe, utrwalone przez tradycję opinie: „Mnogi begovi i age bosanski jesu surovi, žestoki, nemilosèrdni, dadu se nadvladati od strasti, rado gospoduju i prave silu; ali to su mahne svakoga mogućega plemstva što nije učilo knjigu nit je bilo u zgo-

16 „[... nije ni turski Bošnjak Turčin, jer nauk Muhameda nije satro u njemu narav ni ćud slavensku, ni ljubav k običajim i jeziku pradjedovah svojih [...] Njemu je Osmanlija još uvijek tako tuđ, kao svakomu od našega naroda” [Kukuljević Sakcinski 1997: 374]. W podobnym duchu wypowiada się Veber Tkalčević, zastrzegając, że jego uwagi na temat Turków nie odnoszą się do „braci” z Bośni i Hercegowiny: „oni nisu Turci, već Hrvati ili Srblji, što jih volja, muhamedanske vjere: Turci su i njim vazda bili ljuti dušmani” [1886: 72]. Można na marginesie odnotować, że Veber nie uznaje etnicznej odrębności Boszniaków. 
di da izgladi čovječju narav i ljudski duh i sèrdce” [1997: 374]. Krytyka kultury islamu dokonana przez chorwackich podróżników jest rezultatem uprzedzeń, ideologii, planów politycznych oraz/lub postulatów modernistycznych. „Przedmiotem ataków jest bośniacka [także istambulska u Vebera Tkalčevicia - K.P.M.] rzeczywistość oceniana jako efekt niedbalstwa, lenistwa, zabobonu czy fanatyzmu religijnego, a więc zjawisk atakowanych przez zwolenników wiary w postęp społeczny" [Seroka 2013: 97-98]. Z drugiej jednak strony, kiedy - jak w Stambule pod koniec XIX w. - trwal proces modernizacji i europeizacji, widoczny zwłaszcza w odejściu od tradycyjnych strojów, co osłabiło orientalny koloryt, obserwator z Chorwacji, Adolfo Veber Tkalčević z przekąsem konstatował, że oryginalny strój turecki/muzułmański można zobaczyć jedynie w Dubrowniku i Hercegowinie. Wschodni Inny pozostawał więc przedmiotem osądu niezależnie od stopnia zeuropeizowania. „Gdy Turcy nie przystawali do zachodniego stylu życia, nazywani byli barbarzyńcami, kiedy jednak naśladowali Zachód, zwano ich błaznami” [Jezernik 2007: 240].

\section{Fanatyzm i degeneracja}

Wyprawa do Stambułu (Put u Carigrad) Adolfa Vebera Tkalčevicia nosi znamiona ekspedycji naukowej odbywanej w celu weryfikacji obrazu Konstantynopola przedstawionego przez Edmunda de Amicisa w podróży pt. Constantinopoli. Chorwacki duchowny twierdzi, że de Amicis patrzył przez różowe okulary i przyjął turecką perspektywę, dlatego widzi konieczność pokazania prawdziwego oblicza miasta (Pravi Carigrad - tytuł V rozdziału), które wyłoni się po zastosowaniu następujących strategii narracyjnych: nadopuniti, izpraviti, ublažiti [Veber Tkalčević 1886: 101]. W swojej pracy balansuje pomiędzy indywidualną estetyką a dążeniem do „naukowego” oglądu [zob. Pieniążek-Marković 2013: 119-120], jednak wyraźnie ulega „ideologicznym uprzedzeniom”. Wpisanie własnego świadectwa do dyskursu orientalistycznego wymaga transformacji spostrzeżeń osobistych $\mathrm{w}$ twierdzenia formalne/naukowe/obiektywne na temat Orientu - w analizowanym tekście Vebera reprezentowanego przez odwiecznie wrogi islam i Turcję. Stąd jego autobiograficzna narracja stosuje opisy, na podstawie których orientalizm w ogóle, zwłaszcza zaś jego reprezentanci zorientowani na Turcję, będą mogli kształtować naukowe obserwacje [zob. Said 2005: 228], a Europejczycy podejmować właściwe decyzje zmierzające do rozwiązania „kwestii wschodniej”. W osiągnięciu celu niezbędne było odwołanie się do dotychczasowej literatury, zwłaszcza popularnego, opartego na świadectwie osobistym podróżopisarstwa. Intertekstualny dialog (najczęściej jednak: polemikę) z tekstem Włocha, Tkalčević prowadzi z perspektywy katolickiego duchownego, dla którego nawet architektura islamu nie dorównuje chrześcijańskiej, a obserwowane zwyczaje i obrzędy religijne stanowią przejaw fanatyzmu. Meczety budowane są, 
według niego, na jedną modłę, nie dorównują kościołom romańskim czy gotyckim, zaś wzywający na modlitwę głos muezina nie może zastąpić głosu dzwonów kościelnych.

Edward Said przypomina o stałej obecności w świadomości Europejczyków wrażenia przewagi islamu nad katolicyzmem ${ }^{17}$. Chorwacki duchowny odczuwa zatem głęboką potrzebę zaprzeczenia faktom, podważenia pozytywnego obrazu Turcji, rewizji europejskiej pamięci kulturowej i eksponowania fazy schyłku świetności, którą identyfikuje z degeneracją. Funkcję rezultatów „badań” Amicisa i Tkalčevicia zestawvić można $\mathrm{z}$ efektami osiemnastowiecznych projektów Abrahama-Hyacintha Anquetil-Duperrona (szeroko opisał cywilizacje, literaturę, języki Wschodu) i Sir Williama Jonesa (klasyfikacja zamiast opisu, próba „uwięzienia” Orientu w tabelach), naukowców brytyjskich, którzy „odsłonili Orient przed Europą" [Said 2005: 125-130]. Podczas gdy Anquetil-Duperron i Amicis otwierają szeroką panoramę, Jones i Tklačević ją zamykają, kodyfikują, porządkują, porównują i negatywnie wartościują. „Naukowe” zabiegi korekty mają uchronić przed posądzeniem o subiektywizm i stronniczość (które Veber zarzuca Amicisowi).

Z tekstu Vebera Tkalčevicia płyną wnioski o niedojrzałości cywilizacyjnej i kulturowej, a nawet degeneracji świata islamskiego. O fizycznej i moralnej gnuśności mieszkańców Carogrodu (zarówno chrześcijan, jak i muzułmanów) obserwator wnioskuje na podstawie stanu ulic, błota, smrodu i nieprzebranej liczby głodnych, poranionych i umierających na ulicach psów. Nieporównywalny do innych miast stopień zanieczyszczenia Carogrodu pozostaje dla obserwatora tym bardziej niezrozumiały, że osiągany jest przez reprezentantów konfesji nakazującej szczególną dbałość o higienę. Wytłumaczenie sprzeczności autor znajduje w odwołaniu do pasterskiej przeszłości narodu, w którym nawet wiara „koja nalaže, da se bar pet puta na dan umivaju ruke i obraz" nie mogła wykorzenić wrodzonych wad [Veber Tkalčević 1886: 108]. Piętnowane przez Vebera grzechy muzułmanów to niedbałość o czystość i porządek, ociężałość ${ }^{18}$, niechlujstwo,

17 Islam „wykorzystywał tradycje judeohellenistyczne, zapożyczał się twórczo u chrześcijaństwa, mógł się poszczycić wspaniałymi sukcesami militarnymi i politycznymi. Ale to nie wszystko. Kraje islamskie sąsiadują z krainami biblijnymi, a nawet wręcz je obejmują [...]. Od końca siódmego wieku do bitwy pod Lepanto w roku 1571 islam w każdej ze swych form - arabskiej, otomańskiej, północnoafrykańskiej czy hiszpańskiej - dominował lub zagrażał w praktyce europejskiemu chrześcijaństwu. Wrażenie, że Półksiężyc góruje nad Rzymem, a nawet go przyćmiewa, było zawsze obecne w świadomości Europejczyków, zarówno w przeszłości, jak i obecnie” [Said 2005: 122].

18 „[...] ugodnija je vlastita tromost od neslućene čistoće, pa se gad gadom tamani” [Veber Tkalčević 1886: 108]. Bieda i niedbałość, o których wnioskowano na podstawie wyglądu zewnętrznego domów (niskie, drewniane), eksponowane w relacjach podróżników zachodnich i chorwackich, tłumaczone były koczowniczą naturą Turków, którzy 
a ich źródłem - w jego interpretacji - są dogmaty islamu. Do bezczynności skłania, bowiem przekonanie, że wszystko dzieje się zgodnie z literą księgi: „ljudi na tisuće padali žrtvom muhamedanskoga nehaja, koji se tješi kukavnom utjehom, da sve stoji pisano u knjizi” [Veber Takalčević 1886: 109-110]. Wniosek o zaniedbaniu, wiodącym do masowych zgonów „badacz” formułuje na podstawie obserwacji procesji ze zmarłymi, zdążających w kierunku miejsc, gdzie spoczywają imamowie: Husajn, wnuk Mahometa, lub Ali ibn Abi Talib - brat stryjeczny, przybrany syn, a następnie zięć Mahometa, czyli konduktów idących do Karbali lub Wadi-us-Salaam ${ }^{19}$. Pragnienie pochówku na wymienionych nekropoliach związane jest z przekonaniem, że każdy pogrzebany w sąsiedztwie jednego z tych imamów trafia prosto do raju. Liczba konduktów ze zmarlymi, przewożonymi zarówno lądem, jak i Eufratem, zwiększała się zwłaszcza w rocznicę śmierci Husajna lub Alego, dlatego wiele ciał długo oczekujących na transport było już w stanie rozkładu. Karawanom - pisze Veber - towarzyszą szakale, zwabione wonią zgnilizny, i Beduini czyhający na bogactwa składane do grobu razem ze zmarłymi ${ }^{20}$. Kiedy kondukty mogły przejeżdżać przez miasta, zaraza powodowała zgony mieszkańców. Morowe powietrze szerzyło się także od biedaków umierających w pobliżu tych dwóch nekropolii. Brak środków na opłacenie karawany skłaniał ich, bowiem do pieszych wędrówek ku grobom Husajna lub Alego jeszcze za życia. W wyczerpanych pątnikach obserwator widzi ludzkie kreatury („spodobe ljudske”, 1886: 110) a w ich oczach fanatyzm, zwłaszcza gdy wykonują pielgrzymie pieśni nie bacząc na widzów.

Dziwna logika tego wywodu katolickiego duchownego, dla którego pielgrzymki i pieśni pątnicze nie są przecież zaskakującym przejawem praktyk religijnych, każe sądzić, że pątnicy powinni zamilknąć, gdy stają się obiektem obserwacji. W innym miejscu odwaga publicznego wyznawania wiary jest dla Vebera miarą pobożności: „I pobožan je Turčin. [...] nestidi se ipak očito pred svakim izpoviedati svoju vjeru" [1886: 124-125]. Muzułmańska religijność jest jed-

traktują domy i miasta jako tymczasowe siedziby. Jezernik przypomina jednak, że lekceważenie zewnętrznego wyglądu mogło wynikać z chęci ukrycia rzeczywistego bogactwa lub obowiązującego prawa, zgodnie z którym po śmierci gospodarza dom przechodził na własność sułtana, nieopłacalne było zatem inwestowanie [2007: 220-221]. Podobnie w narzekaniach na wąskie ulice czy małe odległości między budynkami nie zwracano uwagi na podporządkowanie zabudowy naturalnej topografii terenu oraz zwyczaj budowania na wzniesieniach w taki sposób, by nie zasłaniać sobie wzajemnie widoku.

19 Veber mówi o miejscowościach Kerbeli i Redžef-ali-u [1886: 108], niewątpliwie jednak chodzi o Karbalę, w pobliżu której zginął Husajn i Wadi-us-Salaam, gdzie spoczywa Ali.

${ }^{20}$ „Diamanti poštropljene posude, biserom posute odjeće, dragocjeno oružje, sila težkih zlatnih novaca, neprocjenive moći nose se u Kerbelu il u Redžef-Ali, gdje jih u podzemnih riznicah nestaje" [Veber Tkalčević 1886: 109]. 
nak w percepcji chorwackiego księdza nierozerwalnie związana $\mathrm{z}$ fanatyzmem, w szczególny sposób przejawiającym się w klasztorach derwiszy, ich tańcu, śpiewach i praktykach pokutnych. Uprzedzenia i przesądy pozwalają autorowi dostrzec w mistycznych praktykach sufizmu wyłącznie fanatyzm. Harmonijne, chóralne śpiewy, rytmiczne ruchy i recytacje określane są zatem jako wycie: „wyją dopóki nie ochrypną, po czym zaczynają wydawać jęki i charczenie, niektórzy tracą świadomość i piana występuje im na usta" [Veber Tkalčević 1886: 126]. Taniec wirujących derwiszy szybko nudzi narratora, który nie rozumie zachwytów nad nimi innych europejskich podróżników. Cytuje także opowieść o klasztorach perskich, gdzie derwisze odprawiają obrzędy, w których ranią się nożami, sam jak mówi - zrezygnował z oglądania tych „rzeźni ludzkich” i „skrajnych przypadków fanatyzmu" [Veber Tkalčević 1886: 129]. Obserwowane praktyki, dzisiaj uznawane za największą atrakcję turystyczną Turcji (zwłaszcza taniec wirujących derwiszy), dla dziewiętnastowiecznego „badacza” nie tylko są potwierdzeniem sądów o „dzikości” tego narodu i kontynentu (dzikiej Azji tradycyjnie przeciwstawia ogładę Europy), lecz także każą sceptycznie myśleć o człowieczeństwie Turków: „Ako su Turci u obće ljudske naravi” [Veber Tkalčević 1886: 127].

\section{6. „Kobietopodobne” stwory}

Relacjonując doświadczenia z wyprawy do Konstantynopola, Veber Tkalčević kontynuuje orientalistyczną opowieść o świecie wymagającym ucywilizowania, lecz równocześnie sugeruje porażkę ewentualnej kulturacji, gdyż musiałaby zostać dokonana na istotach „być może nieludzkich”. Choć jego obserwacje z końca XIX w. nie mówią o ludziach z ogonami [zob. Jezernik, 2007, rozdział 4], to buduje pewną wizję istot człekokształtnych opartą zwłaszcza na segregacji płciowej. Turek jest Inny ze względu na dziką azjatycką naturę, wrodzone barbarzyństwo i fanatyzm [1886: 162], jednak jego człowieczeństwo nie jest tak mocno podawane w wątpliwość, jak w przypadku tureckich kobiet. Katolicki ksiądz w ogóle wiele miejsca poświęca spotykanym kobietom, jednak - jak w całej narracji - ocena płci żeńskiej uzależniona jest od konfesyjnego nacechowania obiektu obserwacji. Rozdział poświęcony mieszkańcom Carogrodu rozpoczyna od opisu chrześcijanek (jako rekompensata za pomijanie ich w relacjach innych podróżników), będących uosobieniem piękna, smaku, uprzejmości, pracowitości i wielu jeszcze zalet. Zgodnie z orientalistyczną perspektywą, Turczynki są bezwstydne, niezgrabne, zaniedbane, pozbawione gustu i kokieteryjne.

Zachowaniem muzułmanek jest zdegustowany od pierwszego kontaktu, czyli jeszcze na statku w drodze do Stambułu. Pobyt w pierwszym tureckim mieście potwierdza negatywny obraz muzułmanek: „po obali na zidu, po panjevih, po piesku, po blatu sjede raskrečene bule, nogu golih do koljena” [1886: 74]. Wyposażony w „szkiełko mędrca” (lornetka) obserwator widzi „więcej”, „lepiej”, „głę- 
biej”, nie daje się więc zwieść różnorodności tkanin i kolorów kobiecego tłumu ${ }^{21}$, lecz pod suknią dostrzega słabe ciało. „Przenikliwość” duchownego kontrastuje z informacjami, że spod szat szczelnie zakrywających kobiety wyziera tylko żólty korzeń nosa („žut korjen nosurine”, 1886: 74). Z jednej strony narrator krytykuje zwyczaj chowania całego ciała, zmuszony jest, bowiem do zgadywania, co znajduje się pod okryciem, z drugiej - informuje o wielkich piersiach zwisających do pasa $^{22}$ i nagich nogach odsłoniętych aż do kolan. Ten rodzaj epatowania „nagością" - z perspektywy europejskiego księdza - dowodzi nieobyczajności muzulmanek. Duchowny zapewne świadomie uderza w największą świętość, jaką jest moralna czystość kobiet ${ }^{23}$.

Tradycyjne stroje muzułmanek podlegają ostrej krytyce, jako niepraktycz$\mathrm{ne}^{24}$, niegustowne i niekobiece. $\mathrm{Z}$ orientalistycznego (i odwołującego się do poniżającego stereotypu) dyskursu Vebera można wnioskować, że niewłaściwy ubiór nie tylko pozbawia cech kobiecości, lecz także odbiera rozum i człowieczeństwo: „Pa ti stvorovi digli glave, taman kao guske, kad se čemu čude” [1886: 74]. Duchowny wyraża nadzieję, że w Carogrodzie zamiast „głupich muzułmańskich gęsi z małego miasteczka” będzie mógł oglądać hurysy, bo to przecież (także?) dla nich wybrał się w tę podróż ${ }^{25}$. Tak zwerbalizowana przez katolickiego duchow-

${ }^{21}$ Jeżeli chorwacki autor miał świadomość, że „jaskrawe kolory przeznaczone są dla dzieci i ludzi o niższym statusie społecznym" [Ruthven 1998: 117], to wyeksponowanie kolorystycznej różnorodności jest jednym z elementów antyislamskiego dyskursu.

${ }^{22}$ Sarkastycznie można zauważyć, że piersi sięgające pępka to wyróżnik kobiet z Dalmacji, więc Veber nie powinien być zaskoczony odkryciem. Pisał o nich sto lat wcześniej Alberto Fortis podróżujący po Weneckiej Dalmacji: „Ogromna długość piersi morlackich kobiet to rzecz poniekąd niezwykła, mogą one podać dziecku noszonemu na plecach sutek przez ramię lub pod pachą" [cyt. za: Jezernik 2007: 62].

${ }^{23}$ Ochrona tego kapitału „znajduje odbicie w semantyce islamu: słowo haram (święte, zabronione, tabu) wywodzi się z tego samego rdzenia, co harim (część domu zarezerwowana dla kobiet) i mahram (grupa krewnych, z którymi kobiecie nie wolno utrzymywać stosunkow seksualnych i do których może ona swobodnie dołączyć)" [Ruthven 1998: 109].

${ }^{24}$ „Ništa nespretnijega, nego bula pod jašmakom u feredži oko posla. Čim prigne glavu, da vidi, što će rukama pograbiti, jašmak joj se od nosa povuče na oči, pa ga mora namieštati. Učvrstivši jašmak, vuče samo desnom rukom perinu, jer joj lieva mora pridržavati pršeću feredžu; ali kad teži teret mora objema rukama vući, onda joj se feredža razširi, pa vidiš, jao, ne znaš što vidiš. Na gladkih prsiju njeke okrajke neznaš čega, košulje li, ili rubca, koje odustajući od posla svaki čas zatiče oko pasa a u suknju" [Veber Tkalčević 1886: 88].

25 „Ali da, to je samo gradić od dvadeset tisuća stanovnika. Pa možda su ovo najsiromašnije,. $\mathrm{Da}$, da, oko onih 1730 pazara, što su gradom raztreseni, puni filigranskog djela od zlata i srebra, moraju se vršiti drugčiji stvorovi, same huriske! Ta, zašto bismo inače putovali u Carigrad” [Veber Tkalčević 1886: 74]. 
nego motywacja odbycia egzotycznej wyprawy zaskakuje. Widząc jedynie „oči, korien nosa i jagodice” [1886: 145], Tkalčević stawia diagnozę o ciałach zużytych, chudych, blado żółtych. Zła kondycja fizyczna, niski wzrost, drobna budowa, skarlałość mają swe źródło $-\mathrm{z}$ orientalistycznego punktu widzenia autora - w muzułmańskich obyczajach nakazujących kobietom przebywanie w zamkniętych pomieszczeniach ${ }^{26}$, wiążą się także $\mathrm{z}$ destrukcyjnym brakiem zajęć, nudą, niezaspokojoną tęsknotą ${ }^{27}$, melancholią, wzdychaniem do chrześcijan (których nie wolno im poślubić, $w$ odróżnieniu od mężczyzn mogących zawierać małżeństwo z chrześcijankami i żydówkami), piciem czarnej kawy i paleniem tytoniu [1886: 147]. Chore wnętrze i odpychający wygląd zewnętrzny (fizyczność, strój, sposób poruszania) składają się na całokształt, który ksiądz katolicki sytuuje na marginesie gatunku ludzkiego, dostrzegając w muzułmankach z Carogrodu zdeformowane człekokształtne postaci, a nawet bardziej przedmioty niż ludzi: „Kada bilo sprieda bilo straga motriš tu spodobu, vazda suncobranom nizko nadstrtu, čini ti se turanom od njekoga vrećom. A kada se vreća držala liepom, makar i od svile bila?" [1886: 149].

Trudno nie dostrzec w ocenach Vebera klasycznej postawy orientalisty, prowadzącego „badania terenowe” mające potwierdzić słuszność tez, z którymi przybywa, prawd o krajowcach zdegenerowanych bądź niedorastających do poziomu ludzi. Niezbędna do „uczłowieczenia” ogłada jest dla nich właściwie nieosiągalna i to $\mathrm{z}$ kilku powodów. Po pierwsze, ze względu na segregację płciową życie toczy się w dwóch odrębnych nurtach, po drugie - w odróżnieniu od „naszej” - komunikacja, muzułmańska dotyczy wyłącznie spraw przyziemnych i materialnych ${ }^{28}$, po trzecie wadliwy jest również ich język, jakoby pozbawiony słów [„neima rieči”, 1886: 163], wypowiadając głębszą myśl zmuszeni są korzystać z języka perskiego, arabskiego lub „europejskiego”. Stopniowe cywilizowanie tureckiego etnosu wy-

${ }^{26}$ „A odakle bliedost i žutost? Posve naravski: u onih malenih kućicach nemože biti prostranih harema, pak niti puno zraka, koji se I tim otimlje, što su rešetke na prozorih tako guste, da se kroz nje nemože razabrati nikakav predmet; a kad izadju na ulicu, usisavaju, mjesto frižkog zraka, istu kužnu sapu, koju su izdahnule" [Veber Tkalčević 1886: 147].

${ }^{27}$ Niemożliwa jest weryfikacja stanu wiedzy Tkalčevicia na temat islamu, nie da się jednoznacznie stwierdzić, czy miał świadomość roli seksualności w budzeniu tęsknoty za rajem, utożsamiania rozkoszy cielesnych z uczuciem przedsmaku raju, przedstawianego jako „«niekończący się orgazm» - stan ekstazy, który prowadzi w końcu do świętej wizji i unii z Bogiem" [Ruthven 1998: 120].

28 „Naše obćenje, okretno i različito, koje sbija šale, razpravlja, poučava, zabavlja; naša potreba buditi i primati čuvstva i misli; ono medjusobno odkrivanje našega bića, kojim se um vježba, a srdce ugrijava, malo tko pozna medju nimi. Njihovi razgovori gmižu malone vaviek po zemlji i razpravljaju ponajviše stvari materijalno potrebne" [Veber Tkalčević 1886: 163]. 
daje się jednak autorowi nieuniknioną koniecznością i jedyną nadzieją na rozwiązanie „wschodniego” problemu, z którym zmaga się Europa. Chorwacki duchowny miał wprawdzie jeszcze inny pomysł na rozwiązanie „kwestii tureckiej”, jednak skromność, przyzwoitość oraz pragnienie uniknięcia posądzenia o pouczanie Europy nakazała mu zachować go dla siebie [1886: 164].

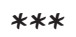

Lektura dziewiętnastowiecznych chorwackich relacji z podróży do Imperium Osmańskiego dowodzi, że niełatwe jest wyzwolenie się spod władzy stereotypów (wyjątek stanowi krótka relacja Pavlinovicia, oddającego głos napotkanym rozmówcom i nie opatrującego komentarzem wyrażanych poglądów, mimo że są antychrześcijańskie i antykatolickie). Spotkanie z kulturą i przedstawicielami islamu w Turcji i Bośni oraz konsekwencjami obecności osmańskiego systemu polityczno-społecznego w Europie nie wiodły ku rewizji, lecz utrwaleniu zakodowanego negatywnego obrazu Innego, którym jest odwieczny wróg - przez Vebera Tkalčevicia kąśliwie nazywany „cywilizator”. Podsumowując wizytę w Bihaću stolicy zajętej przez Turków części Chorwacji - pisze, krytykując wszelkie sojusze z Turcją: „Ovimi kratkimi potezi nacrtana ti je, dragi čitaoče, podosta vjerna slika ovoga civilizatornoga naroda, za koji se Zapad toli silno zanima. Civilizator štiti civilizatora proti slavjanskomu barbarstvu!” [Veber Tkalčević 1998: 108-109]. Niezależnie od intymnego charakteru podróżopisarstwa, w analizowanych tekstach chorwackich niezwykle ważna okazuje się funkcja propagandowa, ideologiczna, oświeceniowa. Idealnym, pożądanym (lecz czy realnym?) odbiorcą publikowanych relacji, poza czytelnikiem chorwackim, był opiniotwórczy odbiorca europejski, mający wpływ na dalekosiężne decyzje polityczne i militarne, które powinny zmierzać w kierunku uwolnienia Europy (i ziem chorwackich) najpierw od Turków, później od wszelkich śladów ich obecności i dominacji, a następnie „uwolnienia” ich od nich samych (ucywilizowania).

\section{LITERATURA}

[Dragičević 2010] - J. Dragičević, Putopisna proza Ivana Kukuljevića Sakcinskoga, [w:] Zbornik o Ivanu Kukuljeviću Skacinskom, red. T. Maštrović, Hrvatski studiji Sveučilišta u Zagrebu $\mathrm{i}$ in., Varaždin.

[Dukić 2007] - D. Dukić, Osmanizam u hrvatskoj književnosti od 15. do sredine 19. stoljeća, [w: Z Zbornik radova Zagrebačke slavističke škole, red. K. Bagić, Filozofski fakultet u Zagrebu, Zagreb.

[Falski 2007] - M. Falski, Pamięć społeczna a ideologia. Z problematyki autoidentyfikacji kultury bośniackiej, „Południowosłowiańskie Zeszyty Naukowe. Język - Literatura - Kultura”, z. 4. 
[Franić 1983] - A. Franić, Hrvatski putopisi romantizma, Narodni list, Zadar.

[Jezernik 2007] - B. Jezernik, Dzika Europa. Bałkany w oczach zachodnich podróżników, przeł. P. Oczko, Universitas, Kraków.

[Kukuljević Sakcinski 1997] - I. Kukuljević Sakcinski, Putovanje po Bosni, [w: ] Izabrana djela, opr. N. Batušić, Matica hrvatska, Zagreb.

[Mažuranić 1842] - M. Mažuranić, Pogled u Bosnu ili kratak put u onu krajinu, učinjen 1839-1840. po Jednom Domorodcu, Tiskara Dra. Ljudevita Gaja, Zagreb.

[Paić-Vukić, Čaušević 2007] - T. Paić-Vukić, E. Čaušević, „Pogled u Bosnu” Matije Mažuranicia kao povijesni izvor, „Prilozi za orijentalnu filologiju”, nr 56.

[Pavlinović 2002] - M. Pavlinović, Puti, [w: ] Hrvatski putopis. Od XVI. stoljeća do danas. Antologijski izbor, red. D. Horvatić, K. Krešimir, Zagreb.

[Pieniążek-Marković 2013] - K. Pieniążek-Marković, Relacje ze spotkania z inna kulturą $w$ dziennikach podróży chorwackiego romantyzmu, [w:] Spotkania międzykulturowe, t. 1: Literaturoznawstwo. Kultura, red. K. Jarząbek, A. Ruttar, S. Sojda, Wydawnictwo Uniwersytetu Śląskiego, Katowice.

[Pieniążek-Marković 2014a] - K. Pieniążek-Marković, Hrvatski romantičari otkrivaju Bosnu, „Sarajevski filološki susreti”, t. II, nr 2.

[Pieniążek-Marković 2014b] - K. Pieniążek-Marković, Bośnia - hortus horridus. Obraz Bośni w podróżach franciszkanów Grgi Marticia i Ivana Frano Jukicia, „Prace Filologiczne. Literaturoznawstwo", t. 7, nr 4 (7).

[Ruthven 1998] - M. Ruthven, Islam, przeł. K. Pachniak, Prószyński i S-ka, Warszawa.

[Said 2005] - E. Said, Orientalizm, przeł. M. Wyrwas-Wiśniewska, Zysk i S-ka, Poznań.

[Seroka 2013] - M. Seroka, Chorwacja turecka - Turcja europejska? Bośnia w podróżopisarstwie epoki jugoslawizmu, „Pamiętnik Słowiański”, t. LXIII, z. 1-2.

[Tkalac 1945] - I. Tkalac, Uspomene iz Hrvatske, Matica hrvatska, Zagreb.

[Todorowa 2008] - M. Todorova, Batkany wyobrażone, przeł. P. Szymor, M. Budzińska, Czarne, Wołowiec.

[Veber Tkalčević 1886] - A. Veber Tkalčević, Put u Carigrad, Matica hrvatska, Zagreb.

[Veber Tkalčević 1998] - A. Veber Tkalčević, Put na Plitvice, [w:] idem, Odabrana pro$z a$, oprac. I. Pranjković, Riječ, Vinkovci.

Krystyna Pieniążek-Marković

\section{CROATIAN ENCOUNTERS WITH ISLAM CULTURE IN THE $19^{\mathrm{TH}}$ CENTURY TRAVELOGUES UNDER THE DOMINION OF STEREOTYPES}

(Summary)

In the article, the accounts of encounters with Islam culture contained in the travelogues of Matija Mažuranić, Ivan Kukuljević Sakcinski, Mihovil Pavlinović and Adolf Veber Tkalčević are analysed. The aforementioned authors were traveling around the Ottoman Bosnia and 
Turkey. In their texts, the perceiving of the Orient culture is determined by the ideological or personal motivations of the authors along with a highly emphasized belonging of Croatia to the Christian world of the West. The confrontation of the cultural self-identification with the notion of Islamic strangeness/hostility/wildness does not allow the travelers to snatch themselves from the dominion of dichotomic divisions and stereotypes as well as from the Orientalist point of view, which in extreme cases deprives Islam believers of their humanity. Inhumane or human not enough, the representative of the foreign values is regarded as a creator of the impure and dangerous reality, therefore, he needs to prevent himself from himself namely, to assimilate into (the Western) civilization. 